\title{
Analysis of Accounting Student Perceptions on the Professional Ethics of Accounting: Case Study at Higher Education in Medan
}

\author{
Amran Harun \\ Politeknik Negeri Medan, Jl. Almamater No.1 Kampus USU Medan 20155 \\ Asriyati \\ Politeknik Negeri Medan \\ Meily Surianti \\ Accounting, Politeknik Negeri Medan
}

\begin{abstract}
The purpose of this study is to identify the tendency of accounting students' perceptions in Medan to professional ethics. Understanding of students' perceptions of professional ethics is very important to be used as a basis for the preparation of teaching materials in lectures. By understanding students' perceptions of ethics, lecturers can give emphasis to certain subjects, adjusted to the dynamics that exist. The expected contribution of the results of this study is primarily in the field of professional ethics studies, where this field of study has become one of the fields of study that stands alone, bearing in mind that ethical issues in practice are still ongoing. Data was collected by distributing questionnaires to 374 accounting students in four tertiary institutions which were selected based on the highest number of active students based on the Dikti forlap data. The tertiary institution that is the place of research is a college that has an employee class. Hypothesis testing is done by a different test.
\end{abstract}

Keywords: Perception, Accounting students, Professional ethics

DOI: $10.7176 / \mathrm{RJFA} / 11-2-11$

Publication date: January $31^{\text {st }} 2020$

\section{Introduction}

Accounting is an information system that prepares and communicates financial and non-financial information for different stakeholders. However, in practice accountants experience various challenges to be able to carry out their duties in presenting financial statements that are reasonable and can be used as a basis for accurate decision making. Many accounting scandals show unethical behavior that has influenced accountants in carrying out their functions (Jones, 2011; Mintz \& Morris, 2014).

Ethical problems in accounting practice still seems to be a problem that seems unresolved until now. It is still fresh in our minds the case of AMRE, a company based in Irving, Texas in 1988. The company's financial officers committed accounting fraud by inflating the value of inventories, revenues, and profit before taxes carried out systematically. This case dragged one of the largest KAP in the world, namely KAP Price Waterhouse. Continued in 2002, the mega scandal Enron, the largest energy company in the world. This Mega scandal dragged KAP Arthur Andersen WW as his external auditor, which ended with the liquidation of the KAP, even though Arthur Andersen WW was recorded as the largest KAP in the world. The Enron Mega scandal also caused fundamental changes in the standards and regulations for the preparation and examination of financial statements.

Scandal after scandal continues to this day. Accounting scandals in recent years that have befallen companies in the world including accounting fraud scandals that befell the well-known electronics company from Japan, Toshiba. In May 2015, Toshiba stated that it was investigating an internal accounting scandal, in which Toshiba made a lie of 1.22 billion USD to report earnings that were not in accordance with the actual conditions (integrityindonesia.com). The next accounting scandal is fraud accounting that befell British Telecom. This company is a giant British company that since the beginning of the second quarter of 2017 has been exposed to the issue of fraud in one of its business lines in Italy. This scandal has also dragged Price Waterhouse Coopers as its public accountant who is considered to have failed to detect fraud (wartaekonomi.co.id). 
In Indonesia, one of the scandals that stick out is the scandal that befell PT Bank Bukopin Tbk, which revised its 2016 financial statements on April 25, 2018. This revision caused a very significant change in reported earnings, where before the revised 2016 profit was recorded at Rp. 1.08 trillion while in 2017 there were only Rp 183.53 billion. Bukopin's management stated that there was an unusual recording of the credit card business income (Kompas.com). Finally, there is the accounting scandal that befell PT Garuda Indonesia (Persero) Tbk, which reported a brilliant performance in 2018 , but was rejected by two Garuda Indonesia commissioners who did not agree to bookkeeping as revenue from cooperation transactions with PT Mahata Aero Teknologi (cnnindonesia.com).

Accountants have obligations to shareholders, creditors, employees, suppliers, the government, the accounting profession, and the wider community. In other words, their obligations extend beyond their immediate clients. Decisions made on information provided by accountants can materially affect the lives of one or all of these stakeholders. Therefore behaving ethically is an important and expected trait (Carroll, 2005). As a result, an accountant is responsible for the consequences of his moral choices not only for his own life but also in the lives of others. An accountant who commits fraud not only damages his own moral existence but also endangers the interests of other community members who depend on him (Catacutan, 2006). Professional ethics is important for accountants and those who depend on information provided by accountants because ethical behavior requires a moral point of view. This can be seen as a formal method for stating to all that work can be trusted (Carroll, 2005).

According to Brinkman (2002), ethics is a discipline that shows things related to evil and goodness, wrong and right, and badness and virtue. Therefore, ethics is used to test moral principles, human behavior, and their efforts to distinguish between good and bad. The development of a code of ethics in organizations can secure the loyalty of business transactions and financial processes, which in turn, affect employee performance, relationships, and company credibility.

The role of the accountant in relation to the preparation of timely and accurate financial statements is very important for decision making by investors, managers and other senior management officials. Compliance with ethics in accounting also helps ensure compliance with internal control systems with standards. Therefore, accountants can identify and measure the waste of resources, investigate, and perform roles that can contribute to the improvement of policy formation and identification of fraud in an organization (Elias, 2002). Unethical behavior not only decreases the reputation and credibility of individuals, but also the company, increasing the likelihood of criminal activities which can result in a decrease in the rate of profit (Sims, 2003). Therefore, it is very important for accountants to strictly adhere to the ethics of the behavioral accounting profession.

Compliance with professional ethics must be instilled early on, namely when prospective accountants receive education in tertiary institutions. Higher education institutions must be able to shape the character of prospective accountants who are ethical and have high integrity, so that when they graduate and become an accountant who engages in the world of practice, able to carry out their functions and maintain public confidence in the accounting profession.

Research conducted by Loe et al., (2000), Gilligan (1982), (McCabe et al., 2006), Costa et al, 201,) Pierce \& Sweeney, (2010) and Ameen, et al (1996) concluded that women have different perceptions and concerns about unethical behavior than men. Whereas Chiu (2003) Kidwell et al. (1987) and Weeks et al. (1999) found that work experience leads to more stringent ethical judgments. Several studies have found that variables are not related. According to Hunt and Vitell (2007), socialization to norms in the workplace at least indirectly influences ethical judgment.

This research will identify how accounting students' perceptions in Medan on ethical issues in carrying out their functions as an accountant. The results of this study are expected to contribute to the development of curriculum and course learning materials related to professional ethics in accounting.

\section{Literature Review}

\subsection{Theory Description}

\subsubsection{Professional Ethics in Accounting}

Ethics is a term that is subject to many interpretations, sometimes contradictory, (Luoma, 1989). Ethical issues are highly relevant issues present in many aspects of real life. This situation can be examined through several branches and under several analytical grids, modern or classic (Filipe et al., 2011). The distinguishing sign of the accounting profession is the acceptance of responsibility to act in the public interest (IFAC, 2005). The main qualities that emerge in the professional body's code of ethics include independence, integrity, objectivity, competence, and 
judgment. For example, ICAEW's introduction to 'Guide to Professional Ethics' (ICAEW, 1997) includes a list of five basic principles that mention or clearly imply all of these qualities, along with other related qualities such as honesty, fairness, honesty, honesty, courtesy, skills and perseverance (Gowthorpe, 2005).

According to Cohen et al. (2001), ethical decision making can be defined as 'decision making in situations where ethical conflicts are present', and this dilemma occurs when there is a conflict of interest between several parties (Blodgett et al., 2001). Therefore, decision making can depend on, inter alia, situational and individual factors. However, according to Rest (1986), the ability to correctly recognize and evaluate ethical dilemmas in decisionmaking situations is a prerequisite needed for good ethical decisions.

Good ethical decision making is influenced by factors that can be divided into two categories, namely individual factors and organizational factors. Ford and Richardson (1994) define the first category as factors related to decision makers and the second as situations where decision makers make decisions. Each factor includes all factors within each individual, such as level, gender, nationality, religion, beliefs, values, education, professional experience, philosophy and value orientation, among many other characteristics. Organizational factors include all factors relating to the situation or environment, such as the influence of the work environment (coworkers and supervisors), organizational culture (the characteristics of the organization itself), opportunities, code of ethics, rewards and sanctions, among others. Individual factors have received increasing attention from Craft researchers (2013). Lehnert et al. (2014) also shows that these factors continue to be studied.

Accounting focuses on presenting business activities in the form of numerical descriptions. Ethical principles encourage the accountant profession to understand and voice the importance of providing accurate and impartial information. This allows business owners to gather the information they need, and the audit agency can make useful judgments. Ethics in accounting is a matter of guidelines and principles. Specific standards are set by regulatory bodies and trade organizations that compose accounting rules, but personal values and professional ethics must guide accountants. This extra layer of ethical judgment helps in making decisions in the face of ambiguity and gray areas.

\subsubsection{Code of Ethics in Accounting}

Ethics in accounting is mainly known as applied ethics, which strongly emphasizes human and business ethics, valuation, moral values, and their application in accounting. In general, the main drivers of accounting ethics are good practices and good standards of professionalism. According to Micewski and Troy (2006), ethical responsibility in the business world is not holistic, but lies under certain contexts of ethical behavior. The majority of companies in the world have institutionalized ethical issues in the accounting process, which increases the potential for conflicts of interest. Violations of ethical rules in corporate financial practices, through financial misstatements, usually damage the organization's reputation, the level of customer satisfaction, and investor confidence in the company.

The International Ethics Standards Board for Accountants, which is also an independent agent, has made a code that sets out the principles that play a role in ethical accounting. These principles cover many facets of ethical behavior for accountants, although unique situations may require judgment calls that are not explicitly reflected in these principles (Gartenstein, 2018).

The International Ethics Standards Board for Accountants establishes five ethical principles for the accounting profession (Gartenstein, 2018), namely: (1) Integrity: Not a set of rules or actions, but rather a state of mind oriented to honesty, directness and commitment to act following the principle rather than for the sake of profit personal; (2) Objectivity: To the extent possible humanly, accountants must not be influenced by the interests or perspectives of the individuals or businesses that employ them. An accountant must also not allow bias or personal interests to influence the numbers that enter the accounting system or the results it produces. Numbers and results must be taken at face value and must encourage conclusions and decisions; (3) Professional Competence and Prudence: The field of accounting is not a static body of knowledge, but rather a changing frame of reference that changes as laws and best practices are redefined over time. It is the responsibility of the ethical accountant to keep abreast of these developments and provide up-to-date information and high quality services to clients; (4) Confidentiality: Accountants handle sensitive information, and it is the ethical responsibility of the accountant not to disclose this information to outsiders who might benefit from it. Likewise, an accountant may not use any information obtained when conducting professional services for personal gain, such as selling shares in a business whose book seems questionable; and (5) Professional Behavior: Like any profession, an accountant must perform duties and responsibilities with due regard to the highest personal and professional standards. This includes completing tasks in a thorough and timely manner, following through on commitments and only receiving payment 
for services that have been provided.

\subsection{Prior Research, Framework for Thinking and Development Hypothesis}

\subsubsection{Gender and Ethical Behavior}

Ethical decision making is influenced by many individual factors, and in particular, many studies report gender differences in ethics (Loe et al., 2000). Women's moral development and ways of reasoning are fundamentally different from those of Gilligan (1982). Some studies show that there are no ethical differences between men and women (McCabe et al., 2006). These findings have generated considerable debate and speculation (Costa et al, 2016)

Some studies show significant differences between men and women while other studies do not show significant differences. Some authors conclude that gender significantly influences decision making (Pierce \& Sweeney, 2010). Ameen, et al (1996) conclude that women have higher perceptions and concerns about unethical behavior, and they tend to act more ethically in similar situations. Men not only act less ethically, but when faced with their lack of ethics, they tend to forgive their mistakes Kidwell, et al (1987). Cohen et al. (2001), in a study applied to accounting students and professionals working in large audit firms, found that women identified ethical problems better than men. Finally, Eweje and Brunton (2010) conclude that female students are ethically more consistent in their responses than their male counterparts. On the other hand, some authors have reached completely opposite conclusions, supporting the idea that gender has no significant influence on ethical decisions.

From previous research and the above frame of mind, a hypothesis was formulated:

H1 : There are differences in perceptions of ethics between accounting students and college students, measured using the dimensions of professional responsibility, public interest, integrity, objectivity and competence

\subsubsection{Work Experience and Ethical Behavior}

Ericsson and Charness (1994) state that ethical decision making is not merely a matter of cross-cutting differences. One key variable that is usually considered to influence ethical behavior and ethical decision making is the level of experience of someone who works in the field. Work experience might be expected to improve ethical decision making and behavior because with experience people gain knowledge about ethical issues and better strategies for working through ethical issues. Gains in this knowledge and strategy, especially when accompanied by the adoption of field norms related to ethics, so that it can lead to better ethical decision making and possibly enhance ethical behavior.

As with other antecedents, conflicting empirical evidence exists between work experience studies and ethical judgments. Chiu (2003) reports that work experience reduces the rigors of ethical judgment, while Kidwell et al. (1987) and Weeks et al. (1999) found that work experience leads to more stringent ethical judgments. Several studies have found that variables are not related. According to Hunt and Vitell (2007), socialization to norms in the workplace at least indirectly influences ethical judgment.

Arlow and Ulrich (1980), studying students and executives, find that executives are more ethical than students, or in other words show that work experience influences the decision making process. Stevens (1984) concluded in a study that applied scenarios to students and business people that students exhibited less ethical behavior than those in business. Furthermore, Kidwell et al. (1987) argue that managers with more years of experience respond more ethically to questionnaires than managers with less experience, which clearly shows the influence of work experience on ethical decision making.

From previous research and the above frame of mind, a hypothesis was formulated:

$\mathrm{H} 2$ : There are differences in perceptions of professional ethics between accounting students who have experience working with those who do not, as measured by professional responsibilities, public interests, integrity, objectivity, and competence.

\section{Purpose and Benefits of Research}

\subsection{Research Puproses}

The purpose of this study is to find out whether:

1. There are differences in perceptions of ethics between students and students. 
2. There are differences in perceptions of ethics between students and students who do not have work experience and who have work experience.

\subsection{Benefits of Research}

The benefits of this research are:

1. The results of research can provide an understanding of students' perceptions of professional ethics is very important to be used as a basis for the preparation of teaching materials in lectures. By understanding students' perceptions of ethics, lecturers can give emphasis to certain subjects, adjusted to the dynamics that exist.

2. Contributing mainly to the field of professional ethics studies, where this field of study has become one of the fields of study that stands alone, bearing in mind that ethical issues in practice are still ongoing.

\section{Research Methodology}

This research is a descriptive quantitative research. Descriptive research is research that seeks to explain phenomena or events in the present.

The parameters used in this study are indicators of perception of professional ethics, using a research instrument in the form of a questionnaire. The indicator used is a modification of the study conducted by Costa et al (2016). The questionnaire will contain several case scenarios that the respondent must comment on. This section discusses research questions, data, and research methods. The questions in the questionnaire identify individual factors that can influence the ethical decision making process of accounting students. For further information, the questionnaire also contained questions about age, gender, work experience, and attendance of courses on ethics.

Data collection: Data is collected by distributing questionnaires to accounting students in the city of Medan. The tertiary institution chosen for research is a university with employee classes, with the largest number of accounting students based on forlap data. The universities chosen to become research sites are UMSU, Panca Budi Development University, Indonesian Methodist University, and Prima University. The questionnaire will be distributed to 379 accounting students in the four tertiary institutions. Students who are sampled are students who have worked and students who have not worked, each with the same number and randomly selected, and has received an auditing course. The sample size of 379 was determined using the Slovin formula, with an error rate of $5 \%$.

Data collected in the form of primary data collected through questionnaires distributed to 379 students in four tertiary institutions in Medan. The tertiary institution where the study was conducted was chosen to use purposive random sampling, namely colleges that have employee classes. While respondents were chosen randomly.

Data analysis was performed first, exploratory univariate analysis to synthesize data (descriptive statistics). After that, conducting free distribution tests around ordinal or nominal data, several specific tests are performed: the Levene test to test the variance equation and Kolmogorov-Smirnov ( $\mathrm{n} \geq 30$ ) or Shapiro-Wilk $(\mathrm{n}<30)$ to test normality. All tests were carried out at a significant level of 5\%. The free distribution test to be carried out is the Mann-Whitney test (comparable to the t-test for parametric statistics), which is done to determine whether two sets of ranks are likely to come from the same population.

The subjects of this research are universities in the city of Medan. The chosen tertiary institution is a tertiary institution which has an employee / worker class. The study population was accounting students in tertiary institutions in the city of Medan, both public and private. Samples were selected by purposive random sampling, ie students who have taken auditing courses, both those who have worked and those who have not yet worked.

\section{Results and Discussion}

\subsection{Research Results}

\subsubsection{Validity Test}

Validity test is done on the basis of decision making Product Moment Validity Test, namely by comparing the value of sig. (2-tailed) with a probability of 0.05 :

1. If the value of sig. (2-tailed) $<0.05$ and Pearson correlation is positive. Then, the questionnaire items are 
valid.

2. If the value of sig. (2-tailed) $<0.05$ and Pearson correlation is negative. Then, the item about the questionnaire was invalid.

3. If the value of sig. (2-tailed) $>0.05$ then the item about the questionnaire is invalid.

Based on the output "Correlations" from the test results, the Sig value is known. (2-tailed) for the relationship or correlation of all items on the questionnaire with a total score of $0,000<005$ and all Pearson correlation values are positive, it can be concluded that all items on the questionnaire are valid. (Test results see attachment).

\subsubsection{Reliability Test}

The basis of the decision in reliability testing uses Cronbach's Alpha. The reliability test can be carried out jointly on all items or questions in the research questionnaire. The basis for decision making in the reliability test is as follows:

1. If the Cronbach's alpha value $>0.60$ then the questionnaire or questionnaire is declared reliable or consistent.

2. Meanwhile, if the Cronbach's alpha value $<0.60$, the questionnaire or questionnaire is declared unreliable or inconsistent.

\section{Reliability Statistics}

\begin{tabular}{|l|l|}
\hline Cronbach's Alpha & N of Items \\
\hline 725 & 20 \\
\hline
\end{tabular}

From the output table above it is known that there are $\mathrm{N}$ of Items (the number of items or items of questionnaire questions) there are 20 items with a Cronbach's Alpha value of 0.725 . Because the Cronbach's Alha value of 0.725> 0.60 , as the basis for decision making in the reliability test above, it can be concluded that all items of the questionnaire questions are reliable.

\subsubsection{Differences Test}

\section{a. By gender}

To find out if there are differences in the average results of each variable in the questionnaire between men and women, then we need to make a hypothesis formulation (alleged research) as follows:

\section{Variable Professional Responsibility}

Ho : There is no average difference in professional responsibility between variables male and female.

$\mathrm{Ha}$ : There is an average difference in the profession responsibility variable between men male and female. Based on the "Independent Samples Test" output table in the "Equal variances assumed" section, the Sig. (2tailed) amounted to $0.011<0.05$, then as the basis for decision making in the independent sample $t$ test, it can be concluded that $\mathrm{Ho}$ is rejected and $\mathrm{Ha}$ is accepted. Thus it can be concluded that there are significant (real) differences between the averages of the professional responsibility variables between men and women.

Public Interest Variable

Ho : There is no average difference in the Public Interest variable between men male and female. $\mathrm{Ha}$ : There is an average difference in the Public Interest variable between men and women.

\begin{tabular}{|c|c|c|c|c|c|c|c|c|c|c|}
\hline \multicolumn{11}{|c|}{ Independent Samples Test } \\
\hline & & \multicolumn{2}{|c|}{$\begin{array}{l}\text { Levene's Test for Equality of } \\
\text { Variances }\end{array}$} & \multicolumn{7}{|c|}{ t-test for Equality of Means } \\
\hline & & \multirow[b]{2}{*}{$\mathrm{F}$} & \multirow[b]{2}{*}{ Sig. } & \multirow[b]{2}{*}{$t$} & \multirow[b]{2}{*}{ df } & \multirow[b]{2}{*}{ Sig. (2-tailed) } & \multirow{2}{*}{$\begin{array}{c}\text { Mean } \\
\text { Difference }\end{array}$} & \multirow{2}{*}{$\begin{array}{l}\text { Std. Error } \\
\text { Difference }\end{array}$} & \multicolumn{2}{|c|}{$\begin{array}{l}95 \% \text { Confidence Interval of the } \\
\text { Difference }\end{array}$} \\
\hline & & & & & & & & & Lower & Upper \\
\hline KPT & $\begin{array}{l}\text { Equal variances } \\
\text { assumed }\end{array}$ & 2.201 & .139 & -.949 & 468 & .343 & -.224 & .237 & -.689 & .240 \\
\hline & $\begin{array}{l}\text { Equal variances not } \\
\text { assumed }\end{array}$ & & & -.830 & 151.055 & .408 & -.224 & .271 & -.759 & .310 \\
\hline
\end{tabular}

Based on the "Independent Samples Test" output table in the "Equal variances assumed" section, the Sig. (2tailed) amounted to $0.343>0.05$ then as the basis for decision making in the independent sample $t$ test, it can be concluded that $\mathrm{H} 0$ is accepted and $\mathrm{Ha}$ is rejected. Therefore, it can be concluded that there is no significant difference between the average in the Public Interest variable between men and women.

\section{Integrity variable}

Ho : There is no average difference in the Integrity variable between men and girl.

$\mathrm{Ha}$ : There is an average difference in the Integrity variable between men and girl. 


\begin{tabular}{|c|c|c|c|c|c|c|c|c|c|c|}
\hline \multicolumn{11}{|c|}{ Independent Samples Test } \\
\hline & & \multicolumn{2}{|c|}{$\begin{array}{l}\text { Levene's Test for Equality of } \\
\text { Variances }\end{array}$} & \multicolumn{7}{|c|}{ t-test for Equality of Means } \\
\hline & & \multirow[b]{2}{*}{$\mathrm{F}$} & \multirow[b]{2}{*}{ Sig. } & \multirow[b]{2}{*}{$t$} & \multirow[b]{2}{*}{ df } & \multirow[b]{2}{*}{ Sig. (2-tailed) } & \multirow{2}{*}{$\begin{array}{l}\text { Mean } \\
\text { Difference }\end{array}$} & \multirow{2}{*}{$\begin{array}{l}\text { Std. Error } \\
\text { Difference }\end{array}$} & \multicolumn{2}{|c|}{$\begin{array}{l}95 \% \text { Confidence Interval of the } \\
\text { Difference }\end{array}$} \\
\hline & & & & & & & & & Lower & Upper \\
\hline IT & $\begin{array}{l}\text { Equal variances } \\
\text { assumed }\end{array}$ & 4.032 & .045 & 2.488 & 468 & .013 & .484 & .195 & .102 & .866 \\
\hline & $\begin{array}{l}\text { Equal variances not } \\
\text { assumed }\end{array}$ & & & 2.296 & 161.236 & .023 & .484 & .211 & .068 & .901 \\
\hline
\end{tabular}

Based on the "Independent Samples Test" output table in the "Equal variances assumed" section, the Sig. (2tailed) amounted to $0.013<0.05$, then as the basis for decision making in the independent sample $t$ test, it can be concluded that $\mathrm{H} 0$ is rejected and $\mathrm{Ha}$ is accepted. Thus it can be concluded that there are significant (real) differences between the averages on the Integrity variable between men and women.

\section{Objectivity Variable}

Ho : There is no average difference in the Objectivity variable between men and girl. $\mathrm{Ha}$ : There is an average difference in the Objectivity variable between men and girl.

\begin{tabular}{|c|c|c|c|c|c|c|c|c|c|c|}
\hline & & $\begin{array}{r}\text { Levene's Tes } \\
\text { Varie }\end{array}$ & fuality of & \multicolumn{7}{|c|}{ t-test for Equality of Means } \\
\hline & & \multirow[b]{2}{*}{$\mathrm{F}$} & \multirow[b]{2}{*}{ Sig. } & \multirow[b]{2}{*}{$t$} & \multirow[b]{2}{*}{ df } & \multirow[b]{2}{*}{ Sig. (2-tailed) } & \multirow{2}{*}{$\begin{array}{c}\text { Mean } \\
\text { Difference }\end{array}$} & \multirow{2}{*}{$\begin{array}{l}\text { Std. Error } \\
\text { Difference }\end{array}$} & \multicolumn{2}{|c|}{$\begin{array}{l}95 \% \text { Confidence Interval of the } \\
\text { Difference }\end{array}$} \\
\hline & & & & & & & & & Lower & Upper \\
\hline$\overline{O T}$ & $\begin{array}{l}\text { Equal variances } \\
\text { assumed }\end{array}$ & 1.538 & .216 & .067 & 468 & .947 & .039 & .579 & -1.099 & 1.177 \\
\hline & $\begin{array}{l}\text { Equal variances not } \\
\text { assumed }\end{array}$ & & & .061 & 160.017 & .951 & .039 & .631 & -1.208 & 1.286 \\
\hline
\end{tabular}

Based on the "Independent Samples Test" output table in the "Equal variances assumed" section, the Sig. (2tailed) amounted to $0.947>0.05$ then as the basis for decision making in the independent sample $t$ test, it can be concluded that $\mathrm{H} 0$ is accepted and $\mathrm{Ha}$ is rejected. Thus it can be concluded that there is no significant difference between the mean in the Integrity variable between men and women.

\section{Competency Variable}

Ho : There is no average difference in the Competency variable between men and girl. $\mathrm{Ha}$ : There is an average difference in the Competency variable between men and girl.

\begin{tabular}{|c|c|c|c|c|c|c|c|c|c|c|}
\hline \multicolumn{11}{|c|}{ Independent Samples Test } \\
\hline & & \multicolumn{2}{|c|}{$\begin{array}{l}\text { Levene's Test for Equality of } \\
\text { Variances }\end{array}$} & \multicolumn{7}{|c|}{ t-test for Equality of Means } \\
\hline & & \multirow[b]{2}{*}{$\mathrm{F}$} & \multirow[b]{2}{*}{ Sig. } & \multirow[b]{2}{*}{$t$} & \multirow[b]{2}{*}{ df } & \multirow[b]{2}{*}{ Sig. (2-tailed) } & \multirow{2}{*}{$\begin{array}{c}\text { Mean } \\
\text { Difference }\end{array}$} & \multirow{2}{*}{$\begin{array}{l}\text { Std. Error } \\
\text { Difference }\end{array}$} & \multicolumn{2}{|c|}{$\begin{array}{l}95 \% \text { Confidence Interval of the } \\
\text { Difference }\end{array}$} \\
\hline & & & & & & & & & Lower & Upper \\
\hline$\overline{k T}$ & $\begin{array}{l}\text { Equal variances } \\
\text { assumed }\end{array}$ & 2.026 & .155 & -1.098 & 468 & .273 & -142 & .129 & -.397 & .112 \\
\hline & $\begin{array}{l}\text { Equal variances not } \\
\text { assumed }\end{array}$ & & & -.942 & 147.943 & .348 & -142 & .151 & -.440 & .156 \\
\hline
\end{tabular}

Based on the "Independent Samples Test" output table in the "Equal variances assumed" section, the Sig. (2tailed) amounted to $0.273>0.05$ then as the basis for decision making in the independent sample $t$ test it can be concluded that Ho is accepted and $\mathrm{Ha}$ is rejected. Thus it can be concluded that there is no significant difference between the mean in the Competency variable between men and women.

\section{b. Based on status}

\section{Variable Professional Responsibility}

Ho : There is no average difference in professional responsibility between variables Already Working and Not Working.

$\mathrm{Ha}$ : There is an average difference in the profession responsibility variable between Already Working and not working..

\begin{tabular}{|c|c|c|c|c|c|c|c|c|c|c|}
\hline \multicolumn{11}{|c|}{ Independent Samples Test } \\
\hline & & \multicolumn{2}{|c|}{$\begin{array}{l}\text { Levene's Test for Equality of } \\
\text { Variances }\end{array}$} & \multicolumn{7}{|c|}{ t-test for Equality of Means } \\
\hline & & \multirow[b]{2}{*}{$\mathrm{F}$} & \multirow[b]{2}{*}{ Sig. } & \multirow[b]{2}{*}{$t$} & \multirow[b]{2}{*}{ df } & \multirow[b]{2}{*}{ Sig. (2-tailed) } & \multirow{2}{*}{$\begin{array}{c}\text { Mean } \\
\text { Difference }\end{array}$} & \multirow{2}{*}{$\begin{array}{l}\text { Std. Error } \\
\text { Difference }\end{array}$} & \multicolumn{2}{|c|}{$\begin{array}{l}95 \% \text { Confidence Interval of the } \\
\text { Difference }\end{array}$} \\
\hline & & & & & & & & & Lower & Upper \\
\hline & $\begin{array}{l}\text { Equal variances } \\
\text { assumed }\end{array}$ & 3.462 & .063 & 3.581 & 468 & .000 & .680 & .190 & .307 & 1.053 \\
\hline & $\begin{array}{l}\text { Equal variances not } \\
\text { assumed }\end{array}$ & & & 3.243 & 183.872 & .001 & .680 & .210 & .266 & 1.093 \\
\hline
\end{tabular}


Based on the "Independent Samples Test" output table in the "Equal variances assumed" section, the Sig. (2tailed) is equal to $0,000<0.05$, so as the basis for decision making in the independent sample $t$ test, it can be concluded that Ho is rejected and $\mathrm{Ha}$ is accepted. Thus it can be concluded that there is a significant (real) difference between the averages of the professional responsibility variables between those who have worked and those who have not yet worked.

\section{Public Interest Variable}

Ho : There is no average difference in the Public Interest variable between Already Working and Not Working.

$\mathrm{Ha}$ : There is an average difference in the variable Public Interest between Already Working and Not working.

\begin{tabular}{|c|c|c|c|c|c|c|c|c|c|c|}
\hline \multicolumn{11}{|c|}{ Independent Samples Test } \\
\hline & & \multicolumn{2}{|c|}{$\begin{array}{l}\text { Levene's Test for Equality of } \\
\text { Variances }\end{array}$} & \multicolumn{7}{|c|}{ t-test for Equality of Means } \\
\hline & & \multirow[b]{2}{*}{$\mathrm{F}$} & \multirow[b]{2}{*}{ Sig. } & \multirow[b]{2}{*}{$t$} & \multirow[b]{2}{*}{ df } & \multirow[b]{2}{*}{ Sig. (2-tailed) } & \multirow{2}{*}{$\begin{array}{l}\text { Mean } \\
\text { Difference }\end{array}$} & \multirow{2}{*}{$\begin{array}{l}\text { Std. Error } \\
\text { Difference }\end{array}$} & \multicolumn{2}{|c|}{$\begin{array}{l}95 \% \text { Confidence Interval of the } \\
\text { Difference }\end{array}$} \\
\hline & & & & & & & & & Lower & Upper \\
\hline KPT & $\begin{array}{l}\text { Equal variances } \\
\text { assumed }\end{array}$ & .341 & .559 & 4.862 & 468 & .000 & 1.079 & .222 & .643 & 1.516 \\
\hline & $\begin{array}{l}\text { Equal variances not } \\
\text { assumed }\end{array}$ & & & 4.672 & 202.086 & .000 & 1.079 & .231 & .624 & 1.535 \\
\hline
\end{tabular}

Based on the "Independent Samples Test" output table in the "Equal variances assumed" section, the Sig. (2tailed) is equal to $0,000<0.05$, so as the basis for decision making in the independent sample $t$ test, it can be concluded that $\mathrm{H} 0$ is rejected and $\mathrm{Ha}$ is accepted. Thus it can be concluded that there is a significant difference between the average in the Public Interest variable between working and not working.

\section{Integrity Variable}

Ho : There is no average difference in the Integrity variable between already working and haven't worked. Ha : There is an average difference in the Integrity variable between working and notworking. Independent Samples Test

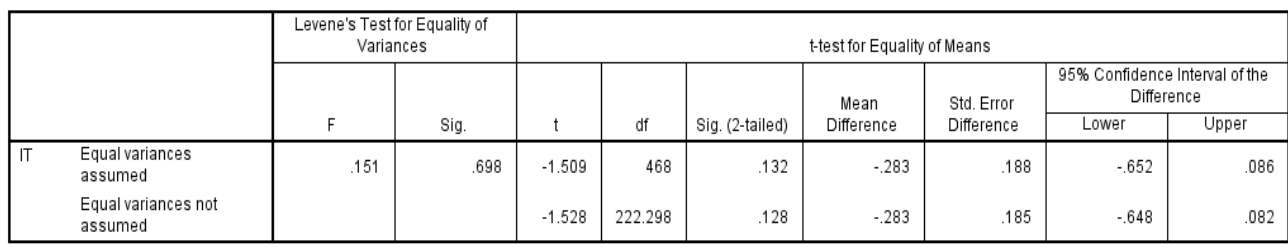

Based on the "Independent Samples Test" output table in the "Equal variances assumed" section, the Sig. (2tailed) is equal to $0,000<0.05$, so as the basis for decision making in the independent sample $t$ test, it can be concluded that $\mathrm{H} 0$ is rejected and $\mathrm{Ha}$ is accepted. Thus it can be concluded that there is a significant difference between the average in the Public Interest variable between working and not working.

\section{Integrity Variable}

Ho : There is no average difference in the Integrity variable between already working and haven't worked. $\mathrm{Ha}$ : There is an average difference in the Integrity variable between working and not working.

\begin{tabular}{|c|c|c|c|c|c|c|c|c|c|c|}
\hline \multicolumn{11}{|c|}{ Independent Samples Test } \\
\hline & & \multicolumn{2}{|c|}{$\begin{array}{l}\text { Levene's Test for Equality of } \\
\text { Variances }\end{array}$} & \multicolumn{7}{|c|}{ t-test for Equality of Means } \\
\hline & & \multirow[b]{2}{*}{$\mathrm{F}$} & \multirow[b]{2}{*}{ Sig. } & \multirow[b]{2}{*}{$t$} & \multirow[b]{2}{*}{ df } & \multirow[b]{2}{*}{ Sig. (2-tailed) } & \multirow{2}{*}{$\begin{array}{l}\text { Mean } \\
\text { Difference }\end{array}$} & \multirow{2}{*}{$\begin{array}{l}\text { Std. Error } \\
\text { Difference }\end{array}$} & \multicolumn{2}{|c|}{$\begin{array}{l}95 \% \text { Confidence Interval of the } \\
\text { Difference }\end{array}$} \\
\hline & & & & & & & & & Lower & Upper \\
\hline OT & $\begin{array}{l}\text { Equal variances } \\
\text { assumed }\end{array}$ & 2.105 & .147 & -.831 & 468 & .406 & -.462 & .556 & -1.555 & .630 \\
\hline & $\begin{array}{l}\text { Equal variances not } \\
\text { assumed }\end{array}$ & & & -.855 & 229.050 & .394 & -.462 & .541 & -1.527 & .603 \\
\hline
\end{tabular}

Based on the "Independent Samples Test" output table in the "Equal variances assumed" section, the Sig. (2tailed) amounted to $0.406>0.05$ then as the basis for decision making in the independent sample $t$ test, it can be concluded that Ho is accepted and $\mathrm{Ha}$ is rejected. Thus it can be concluded that there is no significant difference (real) between the average in the Objectivity variable between working and not working. 


\section{Competency Variable}

Ho: There is no average difference in the Competency variable between already working and not yet working. $\mathrm{Ha}$ : There is an average difference in the Competency variable between working and not working.

Independent Samples Test

\begin{tabular}{|c|c|c|c|c|c|c|c|c|c|c|}
\hline & \multicolumn{2}{|c|}{$\begin{array}{l}\text { Levene's Test for Equality of } \\
\text { Variances }\end{array}$} & \multicolumn{7}{|c|}{ t-test for Equality of Means } \\
\hline & & \multirow[b]{2}{*}{$\mathrm{F}$} & \multirow[b]{2}{*}{ Sig. } & \multirow[b]{2}{*}{ t } & \multirow[b]{2}{*}{ df } & \multirow[b]{2}{*}{ Sig. (2-tailed) } & \multirow{2}{*}{$\begin{array}{l}\text { Mean } \\
\text { Difference }\end{array}$} & \multirow{2}{*}{$\begin{array}{l}\text { Std. Error } \\
\text { Difference }\end{array}$} & \multicolumn{2}{|c|}{$\begin{array}{l}95 \% \text { Confidence Interval of the } \\
\text { Difference }\end{array}$} \\
\hline & & & & & & & & & Lower & Upper \\
\hline$k T$ & $\begin{array}{l}\text { Equal variances } \\
\text { assumed }\end{array}$ & 1.245 & .265 & 2.450 & 468 & .015 & .303 & .124 & .060 & .547 \\
\hline & $\begin{array}{l}\text { Equal variances not } \\
\text { assumed }\end{array}$ & & & 2.187 & 179.983 & .030 & .303 & .139 & .030 & .577 \\
\hline
\end{tabular}

Based on the "Independent Samples Test" output table in the "Equal variances assumed" section, the Sig. (2tailed) amounted to $0.015<0.05$, so as the basis for decision making in the independent sample $t$ test, it can be concluded that $\mathrm{HO}$ is rejected and Ha is accepted. Thus, it can be concluded that there is a significant difference between the average in the Competency variable between working and not working.

\subsection{Discussion}

\subsubsection{Differences in Perception of Ethics Based on Gender}

From the test results, it can be seen that from the five ethical dimensions tested, namely professional responsibility, public interest, integrity, objectivity, and competence, only professional responsibility and integrity show significant differences between students and students while the rest show insignificant differences. These results support research conducted by Ameen, et al (1996), which concluded that women have higher perceptions and concerns about unethical behavior, and they tend to act more ethically in the same situation. Men not only act less ethically, but when faced with their lack of ethics, they tend to forgive their mistakes Kidwell, et al (1987).

\subsubsection{Differences in Perception of Ethics by Status}

From the test results it can be seen that from the five ethical dimensions tested, namely professional responsibility, public interest, integrity, objectivity, and competence, dimensions of professional responsibility, public interest, and competence show significant differences between students / students who have worked, whereas the dimensions of objectivity and integrity show the opposite results.

These results support the opinion of Arlow and Ulrich (1980), study students and executives, find that executives are more ethical than students, or in other words show that work experience influences the decision making process and Kidwell et al. (1987) argue that managers with more years of experience respond more ethically to questionnaires than managers with less experience, which clearly shows the influence of work experience on ethical decision making.

\section{Conclusion and Suggestion}

\subsection{Conclusion}

From the results of the study it can be concluded that for ethical perceptions based on gender, of the five dimensions tested, only two dimensions showed significant differences, whereas for ethical perceptions based on status, there were three dimensions that showed significant differences. These results show that ethical issues are more influential on students who are already working (based on status), compared to college students (based on gender).

\subsection{Suggestion}

From the conclusions above, it is recommended that the ethical content in the accounting curriculum continue to be improved, especially for students who are not working, so that they do not commit ethical violations when they work later, and support the establishment of reliable ethical accountants.

\section{References}

Ameen, E. C., Guffey, D. M., \& McMillan, J. 1996. Gender differences in determining the ethical sensitivity of future accounting professionals. Journal of Business Ethics, vol. 15 no.5 pp. 591-597. 
Arlow, P., \& Ulrich, T. A. 1980. Business ethics, social responsibility and business students: An empirical comparison of Clark's study. Akron Business and Economic Review vol. 11 no. 3 pp. 17-23.

Baihaki. 2018. Laporan keuangan bukopin "tersandung" kasus kartu kredit, ini penjelasan dirut https://ekonomi.kompas.com/read/2018/05/03/070000026/ laporan-keuangan-bukopin-tersandung-kasuskartu-kredit-ini-penjelasandirut?Pa ge=all. Diakses tanggal 14 Agustus 2019 pukul 19.20.

Blodgett, J. G., Chaun Lu, L., Rose, G. M., \& Vitelli, S. J. 2001. Ethical sensitivity to stakeholder interests: A cross-cultural comparison. Journal of the Academy of Marketing Science vol. 29 no.2 pp. 190-202.

Brinkmann, J. 2002. Marketing ethics as professional ethics: Concepts, approaches, and typologies. Journal of Business Ethics vol. 41 no.1/2 pp. 159-177

Carroll, R.A., 2005. Model for ethical education in accounting, In Gowthorpe, C. and Blake J. (Eds.) "Ethical Issues in Accounting" (2nd ed) .Taylor and Francis e-Library pp. 149-164.

Catacutan, R. 2006. A humanistic perspective in teaching business ethics in accountancy. Paper presented at the 6th Annual Ben-Africa Conference University of Stellenbosch, Capetown, South Africa26-28 Strathmore University Nairobi, Kenya, pp. 1-6.

Cohen J. R., Pant L. W., \& Sharp, D. J. 2001. An examination of differences in ethical decisionmaking between Canadian business students and accounting professionals. Journal of Business Ethics vol. 30 no.4 pp.319336.

Cohen J. R., Pant L. W., \& Sharp, D. J. 2001. An examination of differences in ethical decisionmaking between Canadian business students and accounting professionals. Journal of Business Ethics vol. 30 no. 4 pp. 319 336.

Craft, J. 2013. A review of the empirical ethical decision-making literature: 2004-2011. Journal of Business Ethics vol. 117 no. 2 pp. $221-259$.

Elias, R. Z. 2002. Determinants of earning management ethics among accountants. Journal of Business Ethics vol. 40 no. 1 pp. 33-45.

Eweje, G., \& Brunton, M. 2010. Ethical perceptions of business students in a New Zealand university: Do gender, age and work experience matter?. Business Ethics: A European Review vol.19 no.1 pp. 95-111.

Filipe, J.A., M. Alberto, M. Ferreira et al. 2011. An ethical issue in anti-commons management aquaculture case in Portugal. International Journal of Academic Research vol. 3 no.1 pp. 250-252.

Ford, R. C., \& Richardson, W. D. 1994. Ethical decision making: A review of the empirical literature. Journal of Business Ethics vol.13 pp. 829-838.

Gilligan, C. 1982. In a Different Voice: Psychological Theory and Women's Development. Harvard University Press, Cambridge, MA.

Gowthorpe, C. 2005. Ethical issues and the auditor. In Gowthorpe, C. and Blake J. (Eds.) "Ethical Issues in Accounting" (2nd ed). Taylor and Francis e-Library pp. 135-149.

Hunt, S.D. and Vitell, S.J. 1986. A general theory of marketing ethics. Journal of Macromarketing vol. 6 pp. 5 16.

International Federation of Accountants (IFAC). 2005. Code of ethics for professional accountants pp. 4-14.

Jones, M. J. 2011. Creative accounting, fraud and international accounting scandals. Wes Sussex: John Wiley.

Kidwell, J. M., Stevens, R. E., \& Bethke, A. L. 1987. Differences in the ethical perceptions between male and female managers: Myth or reality? Journal of Business Ethics vol. 6 pp. 489-493.

Lehnert, K., Park Y.,\& Singh, N. 2014. Researchnote and review of the empirical ethical decision making literature: Boundary conditions and extensions. Journal of Business Ethics.

Loe, T. W., Ferrell, L., \& Mansfield, P. 2000. A review of empirical studies assessing ethical decision-making in business. Journal of Business Ethics vol. 25 pp. 185-204.

Luoma, G.A., 1989. Can ethics be taught?. Management Accounting vol. 1 pp. 14-16.

McCabe, A., Ingram, R. and Dato-On, M. 2006. The business of ethics and gender. Journal of Business Ethics vol. 64 pp. 101-16.

Micewski, E. R., \& Troy, C. 2006 . Business ethics - Deontologically revisited. Journal of Business Ethics vol. 72 no. 1 pp. 17-25.

Mintz, S. M., \& Morris, R. E. 2014. Ethical Obligations and Decision-Making in Accounting: Text and Cases (3rd ed.). New York, NY: McGraw-Hill Education.

Pierce, B., \& Sweeney, B. 2010. The relationship between demographic variables and ethical decision making of trainee accountants. International Journal of Auditing, vol. 14 pp. $79-99$.

Pratiwi, Hesti Rika. 2019. Membedah keanehan laporan keuangan garuda indonesia 2018. https://www.cnnindonesia.com/ekonomi/2019042420472692389396/mem keuangan-garuda-indonesia-2018. Diakses pada 13 Agustus 2019 pukul 19.20

Priantara, Diaz. 2017. Ketika skandal fraud akuntansi menerpa british telecom dan pwc. https://www.wartaekonomi.co.id/read145257/ketika-skandal fraud akuntansi -menerpa-british-telecom-danpwc.html. Diakses pada tanggal 14 Agustus 2019 pukul 15:50. 
Rest, J. (1986). Moral developments: Advances in research and theory. New York, NY: Praeger.

Sari, Kartika. 2017. Skandal keuangan perusahaan https://integrityindonesia com/id/blog/2017/09/14/skandal-keuangan-perusahaan-toshiba/. Diakses pad tanggal 13 Agustus 2019 pukul 19.20.

Sims, R. R. 2003. Ethics and corporate social responsibility: Why giants fall. Westport, CT: Praeger Press

Stevens, G. E. 1984. Business ethics and social responsibility: The response of present and future managers. Akron Business and Economic Review Fall vol. 15 pp. 6-11

Weeks, W. A., Moore, C. W., McKinney, J. A., \& Longenecker, J. G. 1999. The effects of gender and career stage on ethical judgement. Journal of Business Ethics vol. 20 no.4 pp. 301-313. 